\title{
An International Study of Knowledge Sharing in Human Resource Management at Higher Education Institutions
}

\author{
Rubeshan Perumal \\ Sadhasivan Perumal \\ Loganathan Narayansamy Govender
}

\begin{abstract}
The knowledge economy of the $21^{\text {st }}$ century has redefined human resource management as a strategic component of organisation success. This is particularly true in institutions of higher education, where knowledge serves not only as an organisational driver, but represents the very core of these institutions. Both the nature of these institutions, and the academics who work within them form part of a valuable institutional knowledge pool. Knowledge sharing within such an organisation is vital to its sustainability and viability. This study employs a cross-sectional survey design administered in three countries to respondents employed in the human resource divisions of higher education institutions to explore the theme of knowledge sharing. The study identified formal policies, practices, and procedures to be promoters of knowledge sharing. Organisational structure, political interference, poor communication between employees, and a command and control approach were considered to be barriers to knowledge sharing, particularly in South Africa and Mauritius. Silo compartmentalisation of organisations pose a threat to the transfer of knowledge between departments, and there is still much work that needs to be done before knowledge can be trusted to be reliable, current, and useful for decision making.
\end{abstract}

Keywords: Knowledge management, Knowledge sharing, Higher education institutions, Human Resource Management. 


\section{Background}

The knowledge economy in the $21^{\text {st }}$ century has had a significant impact on the human resource function in organizations. This century has embraced a major shift in the human resource management (HRM) function. It transformed from a bureaucratic 'personnel management' operation a few decades ago, to a human resource department with integrated functions which support the corporate strategy and the organization's competitive advantage (Chivu \& Popescu 2008). In this vein, Lengnick-Hall \& Lengnick-Hall (2003:178) state that whilst traditional human resource management (HRM) operated within confined boundaries, the role of HRM in the knowledge economy has expanded both within the organization and beyond. They posit that the emphasis on human resource practices is to create environments conducive to learning, and the acquisition, sharing and dissemination of knowledge within organizations.

Svetlik and Stavrou-Costea (2007:197) advocate that immense benefits could be derived if human resource management and knowledge management are integrated, where one reinforces and supports the other in improving organizational effectiveness and performance. As a consequence, Smith \& Schurink (2005) claim that knowledge management is a deliberate means of eliciting essential knowledge from knowledgeable people and getting it into action by sharing it with the people who require it at the right time to enhance organizational performance. They further assert that knowledge management entails a complex process that is influenced by a number of variables both within and outside the organization.

Cloete \& Bunting (2000:85) claim that the most critical challenge for higher education institutions in South Africa in the 21st century will be in the human resource management sector. These challenges relate to the attraction, recruitment and retention of high quality employees, and the need to change to the demographic profile of employees in terms of the provisions of the Employment Equity Act. In order to meet the human resource needs in a highly competitive environment, Cloete \& Bunting (2008:86) recommend the following initiatives for the $21^{\text {st }}$ century higher education sectors:

- Improvement in the conditions of service of staff;

- Creation of new and innovative recruitment and retention strategies;

- A balance between driving the equity programmes and quality of new recruits; 
- An integrated institution-wide human resource and staff development strategy; and

- The improvement of leadership and management capacity in the new complex South African higher education environment.

According to Ivancevich (2001:8) there is a need for a strategic perspective on human resource management when organizations become larger and complex. As higher education institutions are regarded as large and complex institutions, the need to integrate strategies with human resource management is adequately demonstrated.

Knowledge management is the process of capturing the collective expertise and intelligence in an organization and utilizing them to create innovation through continuous organizational learning (Davenport \& Prusak 1998: 5). Herling \& Provo (2000:7) posit that any theory of knowledge management must embrace concepts such as knowledge assessment, creation, storage, distribution, and its application to the business and organizational strategy.

According to Scarbrough et al. (1999) notwithstanding the attention that knowledge management attracted to other sectors of the organization, its beneficial role for human resource management has not been fully appreciated. They identified knowledge formation and acquisition, knowledge utilization, and knowledge retention as key knowledge management processes. Technology cannot on its own cannot capture and manage innovative knowledge. The technology perspective of knowledge management focuses on flows of information through IT tools such as intranets. Due to the view that knowledge management is predominantly technology driven initiative, the human resource management focus has been neglected. It is argued that knowledge management is a process and not a technology and is directly linked to the ways in which people work. A supportive culture is viewed as important for knowledge management, complemented with HR policies that link rewards to individual employee contributions. This would create an internal ethos of knowledge creation and knowledge sharing.

There is no universally accepted definition of the concept knowledge. The constructivist view holds that knowledge is a subjective state in individuals minds embedded in organizations and communities (Davenport \& Prusak 1998; Lang 2001 \& Spender 1998 cited in Svetlik \& Stavrou Costea 2007). The constructivist approach to knowledge relies on the difference 
between information and knowledge. Information is organized data whilst knowledge is meaningful information. The objectivist approach considers knowledge management as a conscious strategy of getting the right knowledge to the right people at the right time. This approach helps employees share and put information into action in ways that would improve organizational performance (O’Dell \& Grayson 1998). Svetlik and Stavrou Costea, (2007) view the two approaches as meaning one and the same as they complement each other. Drucker (1993:38) describes knowledge as the most important resource in a knowledge society. He also maintains that:

Knowledge is not impersonal like money. Knowledge does not reside in a book, a data bank, a software program. These contain only information. Knowledge is always embodied in a person, taught and learned by a person, used or misused by a person (Drucker 1993:191).

According to Gottschalk (2005:15) knowledge sharing has received wide attention in management literature. Markus (2001:57) identifies four types of knowledge replication situations.

- The first is termed 'shared knowledge producers'. In this situation knowledge re-users could be close to or distant from the knowledge producers.

- The second sharing is regarded as the 'shared work practitioners' where people share a similar practice community. These practitioners could be specialists who occupy similar roles in different locations, work units, or organizations.

- The third initiative is called 'expertise seeking novices'. This entails novices seeking access to experts and expertise from the knowledge creators.

- The fourth knowledge sharing mechanism is 'secondary knowledge miners'. This situation involves data mining where analysts extract knowledge from records that were collected by others, sometimes unknown to the re-user of the knowledge, and adapts such knowledge for use in different purposes. In order to maximize the potential use of knowledge resources it is necessary to implement knowledge transfer mechanisms. 
According to Mayo (1998) collaboration amongst employees regarding work related issues and the sharing of knowledge are lacking in organizations. This view is reinforced by Cole-Gomolski (1997) as he claims that efforts to deploy KM group-wide in the organization are frequently met with employee resistance to share their expertise. Forbes (1997) argues that the likely reasons for the display of this attitude is attributed to employees being competitive in nature and are therefore inclined to hoard rather than share the knowledge they possess. On the other hand, Ostro (1997) reports that the results of an extensive multi-organizational study found that the main reason for knowledge not being shared was that employees did not realize that their experience was material to fellow employees. Mayo (1998) makes the point that the recruitment function should be expanded to explore methods of sharing knowledge with new employees, as well as to assess what new knowledge new employees could bring to the organization. He suggests that the orientation process with new recruits should involve the capturing of their knowledge and experience. Although most new employees bring useful specialist experience with them, few organizations tap this rich reservoir of knowledge.

Mayo (1998) makes reference to the capture of experience and expertise of those employees who exit the organization. In this regard he states that: 'when people leave, the HR department asks their company keys and so on. Why not conduct a recruitment interview in reverse to retrieve information'. Mayo (1998) further argues that there is a general reluctance by organizations to trust employees with information. He claims that a common excuse tendered by organizations that withhold information is one of 'commercial sensitivity'.

There is a paucity of information on the status of knowledge management in higher education institutions, where there the full potential of knowledge management has yet to be materialised. This study aims to contribute to the minimal existing knowledge in the application of knowledge management at higher education institutions in three developing countries, with a particular focus on knowledge sharing.

\section{Methods}

Structured questionnaires were administered to the respondent sample comprising 91 human resource practitioners in higher education institutions in South Africa, Mauritius and India. Five higher education institutions in South Africa, 
three in Mauritius and three in India participated in the study and hence constituted the target population for the survey. The respondents comprised senior HR managers, HR line managers and HR supervisors of the participating institutions and were deemed representative of the population under study. The basis for selecting the study settings have been discussed in previous publications (Govender, Perumal \& Perumal 2018). All data was analysed using SPSS software (SPSS 23.0, Armonk NY: IBM Corp). For all statistical comparisons, a 5\% level of significance was used. Pearson's Chi-square Test or Fishers Exact Test was used to assess the association between categorical variables of interest.

Ethical clearance was obtained from the Human \& Social Science Ethics Committee of the University of KwaZulu-Natal.

\section{Results}

\begin{tabular}{|l|l|l|l|l|l|l|l|l|}
\hline \multirow{3}{*}{ Gender } & \multicolumn{9}{|l|}{ Country } \\
\cline { 2 - 9 } & India & \multicolumn{1}{|l|}{ Mauritius } & \multicolumn{2}{l|}{ RSA } & \multicolumn{2}{|c|}{ Total } \\
\cline { 2 - 9 } & Count & $\%$ & Count & $\%$ & Count & $\%$ & Count & $\%$ \\
\hline Male & 13 & 59.1 & 7 & 36.8 & 31 & 62 & 51 & 56 \\
\hline Female & 9 & 40.9 & 12 & 63.2 & 19 & 38 & 40 & 44 \\
\hline Total & 22 & 100 & 19 & 100 & 50 & 100 & 91 & 100 \\
\hline
\end{tabular}

Fig 1: Gender distribution of respondents across survey sites

\begin{tabular}{|c|c|c|c|c|c|c|c|c|}
\hline \multirow{3}{*}{ Age } & \multicolumn{6}{|c|}{ Country } & \multirow{2}{*}{\multicolumn{2}{|c|}{ Total }} \\
\hline & \multicolumn{2}{|c|}{ India } & \multicolumn{2}{|c|}{ Mauritius } & \multicolumn{2}{|l|}{ RSA } & & \\
\hline & Count & $\%$ & Count & $\%$ & Count & $\%$ & Count & $\%$ \\
\hline$\leq 25$ & 1 & 4.5 & 0 & 0 & 1 & 2 & 2 & 2.2 \\
\hline $26-35$ & 3 & 13.6 & 11 & 57.9 & 11 & 22 & 25 & 27.5 \\
\hline $36-45$ & 9 & 40.9 & 33 & 15.8 & 16 & 32 & 28 & 30.8 \\
\hline $46-55$ & 6 & 27.3 & 3 & 15.8 & 19 & 38 & 28 & 30.8 \\
\hline$\geq 56$ & 3 & 13.6 & 2 & 10.5 & 3 & 6 & 8 & 8.8 \\
\hline Total & 22 & 100 & 19 & 100 & 50 & 100 & 91 & 100 \\
\hline
\end{tabular}

Fig 2: Age distribution of respondents across survey sites 
Female respondents accounted for $44 \%$ of the total sample; the majority of respondents were male in India (59.1\%) and South Africa (62\%), while females comprised $63.2 \%$ of the respondents in Mauritius.

Overall, respondents from the three countries had similar age distributions with the majority of respondents between 26 and 55 years old.

Figures 3 to 11 present the results regarding to aspects of knowledge sharing.

\begin{tabular}{|l|l|l|l|l|}
\hline \multirow{4}{*}{ Item } & \multirow{2}{*}{ Response } & \multicolumn{3}{|c|}{ Country } \\
\cline { 3 - 5 } & $\begin{array}{l}\text { India } \\
\mathrm{n}=22\end{array}$ & $\begin{array}{l}\text { Mauritius } \\
\mathrm{n}=19\end{array}$ & $\begin{array}{l}\text { RSA } \\
\mathrm{n}=50\end{array}$ \\
\hline \multirow{4}{*}{$\begin{array}{l}\text { Current HR policies } \\
\text { and procedures }\end{array}$} & Strongly disagree & 0 & 0 & 0 \\
\cline { 2 - 5 } & Disagree & 0 & 0 & 8 \\
\cline { 2 - 5 } & Neutral & 0 & 0 & 10 \\
\cline { 2 - 5 } & Agree & 81.8 & 68.4 & 64 \\
\cline { 2 - 5 } & Strongly agree & 18.2 & 31.6 & 18 \\
\cline { 2 - 5 } & $\mathrm{p}=0.16$ & & & \\
\hline
\end{tabular}

Fig 3: Current HR policies and procedures as encouragers of knowledge sharing

\begin{tabular}{|l|l|l|l|l|}
\hline \multirow{4}{*}{ Item } & \multirow{4}{|l|}{ Country } \\
\cline { 3 - 5 } & Response & $\begin{array}{l}\text { India } \\
\mathrm{n}=22\end{array}$ & $\begin{array}{l}\text { Mauritius } \\
\mathrm{n}=19\end{array}$ & $\begin{array}{l}\text { RSA } \\
\mathrm{n}=50\end{array}$ \\
\hline \multirow{4}{*}{$\begin{array}{l}\text { Unwritten } \\
\text { HR practices } \\
\text { and } \\
\text { procedures }\end{array}$} & Strongly disagree & 0 & 10.5 & 4 \\
\cline { 2 - 5 } & Disagree & 18.2 & 0 & 8 \\
\cline { 2 - 5 } & Neutral & 63.6 & 47.4 & 20 \\
\cline { 2 - 5 } & Agree & 18.2 & 21.1 & 56 \\
\cline { 2 - 5 } & Strongly agree & 0 & 21.1 & 12 \\
\cline { 2 - 5 } & $\mathrm{p}<0.05$ & \multicolumn{3}{|l}{} \\
\hline
\end{tabular}

Fig 4: Unwritten HR practices and procedures as encouragers of knowledge sharing 


\begin{tabular}{|l|l|l|l|l|}
\hline \multirow{4}{*}{ Item } & \multirow{4}{|c|}{} & \multicolumn{3}{|l|}{ Country } \\
\cline { 3 - 5 } & Response & $\begin{array}{l}\text { India } \\
\mathrm{n}=22\end{array}$ & $\begin{array}{l}\text { Mauritius } \\
\mathrm{n}=19\end{array}$ & $\begin{array}{l}\text { RSA } \\
\mathrm{n}=50\end{array}$ \\
\hline \multirow{5}{*}{$\begin{array}{l}\text { Job } \\
\text { manuals }\end{array}$} & Strongly disagree & 0 & 0 & 0 \\
\cline { 2 - 5 } & Disagree & 4.5 & 5.3 & 6 \\
\cline { 2 - 5 } & Neutral & 13.6 & 5.3 & 10 \\
\cline { 2 - 5 } & Agree & 72.7 & 68.4 & 72 \\
\cline { 2 - 5 } & Strongly agree & 9.1 & 21.1 & 12 \\
\cline { 2 - 5 } & $\mathrm{p}=0.97$ & \multicolumn{3}{|l}{} \\
\hline
\end{tabular}

Fig 5: Job manuals as encouragers of knowledge sharing

\begin{tabular}{|l|l|l|l|l|}
\hline \multirow{4}{*}{ Item } & & \multicolumn{3}{|l|}{ Country } \\
\cline { 3 - 5 } & Response & $\begin{array}{l}\text { India } \\
\mathrm{n}=22\end{array}$ & $\begin{array}{l}\text { Mauritius } \\
\mathrm{n}=19\end{array}$ & $\begin{array}{l}\text { RSA } \\
\mathrm{n}=50\end{array}$ \\
\hline \multirow{4}{*}{$\begin{array}{l}\text { HR filing } \\
\text { systems }\end{array}$} & Strongly disagree & 0 & 0 & 0 \\
\cline { 3 - 5 } & Disagree & 4.5 & 5.3 & 6 \\
\cline { 2 - 5 } & Neutral & 31.8 & 15.8 & 12 \\
\cline { 2 - 5 } & Agree & 50 & 52.6 & 72 \\
\cline { 2 - 5 } & Strongly agree & 13.6 & 26.3 & 10 \\
\cline { 2 - 5 } & $\mathrm{p}=0.38$ & \multicolumn{3}{|l}{} \\
\hline
\end{tabular}

Fig 6: HR filing systems as encouragers of knowledge sharing 


\begin{tabular}{|l|l|l|l|l|}
\hline \multirow{4}{*}{ Item } & \multirow{4}{|l|}{ Country } \\
\cline { 3 - 5 } & Response & $\begin{array}{l}\text { India } \\
\mathrm{n}=22\end{array}$ & $\begin{array}{l}\text { Mauritius } \\
\mathrm{n}=19\end{array}$ & $\begin{array}{l}\text { RSA } \\
\mathrm{n}=50\end{array}$ \\
\hline \multirow{4}{*}{$\begin{array}{l}\text { Workflow } \\
\text { processes }\end{array}$} & Strongly disagree & 0 & 5.3 & 0 \\
\cline { 2 - 5 } & Disagree & 4.5 & 0 & 6 \\
\cline { 2 - 5 } & Neutral & 54.5 & 21.1 & 24 \\
\cline { 2 - 5 } & Agree & 31.8 & 57.9 & 52 \\
\cline { 2 - 5 } & Strongly agree & 9.1 & 15.8 & 18 \\
\cline { 2 - 5 } & $\mathrm{p}=0.08$ & \multicolumn{2}{|l}{} \\
\hline
\end{tabular}

Fig 7: Workflow processes as encouragers of knowledge sharing

\begin{tabular}{|l|l|l|l|l|}
\hline \multirow{4}{*}{ Item } & \multirow{4}{|l|}{ Country } \\
\cline { 3 - 5 } & Response & $\begin{array}{l}\text { India } \\
\mathrm{n}=22\end{array}$ & $\begin{array}{l}\text { Mauritius } \\
\mathrm{n}=19\end{array}$ & $\begin{array}{l}\text { RSA } \\
\mathrm{n}=50\end{array}$ \\
\hline \multirow{5}{*}{$\begin{array}{l}\text { Organisational } \\
\text { structures }\end{array}$} & Strongly disagree & 9.1 & 10.5 & 6 \\
\cline { 2 - 5 } & Disagree & 54.5 & 26.3 & 14 \\
\cline { 2 - 5 } & Neutral & 36.4 & 10.5 & 18 \\
\cline { 2 - 5 } & Agree & 0 & 47.4 & 60 \\
\cline { 2 - 5 } & Strongly agree & 0 & 5.3 & 2 \\
\cline { 2 - 5 } & $\mathrm{p}<0.0001$ & \multicolumn{3}{|l}{} \\
\hline
\end{tabular}

Fig 8: Organisational structures as barriers to knowledge sharing 


\begin{tabular}{|l|l|l|l|l|}
\hline \multirow{4}{*}{ Item } & \multicolumn{4}{|l|}{ Country } \\
\cline { 3 - 5 } & Response & $\begin{array}{l}\text { India } \\
\mathrm{n}=22\end{array}$ & $\begin{array}{l}\text { Mauritius } \\
\mathrm{n}=19\end{array}$ & $\begin{array}{l}\text { RSA } \\
\mathrm{n}=50\end{array}$ \\
\hline \multirow{4}{*}{$\begin{array}{l}\text { Political } \\
\text { interference }\end{array}$} & Strongly disagree & 9.1 & 15.8 & 2 \\
\cline { 2 - 5 } & Disagree & 36.4 & 10.5 & 16 \\
\cline { 2 - 5 } & Neutral & 40.9 & 26.3 & 62 \\
\cline { 2 - 5 } & Agree & 9.1 & 15.8 & 18 \\
\cline { 2 - 5 } & Strongly agree & 4.5 & 31.6 & 2 \\
\cline { 2 - 5 } & $\mathrm{p}<0.05$ & \multicolumn{3}{|l}{} \\
\hline
\end{tabular}

Fig 9: Political interference as a barrier to knowledge sharing

\begin{tabular}{|l|l|l|l|l|}
\hline \multirow{4}{*}{ Item } & \multicolumn{4}{|l|}{ Country } \\
\cline { 3 - 5 } & Response & $\begin{array}{l}\text { India } \\
\mathrm{n}=22\end{array}$ & $\begin{array}{l}\text { Mauritius } \\
\mathrm{n}=19\end{array}$ & $\begin{array}{l}\text { RSA } \\
\mathrm{n}=50\end{array}$ \\
\hline \multirow{4}{*}{$\begin{array}{c}\text { Communicatio } \\
\mathrm{n} \quad \text { channels } \\
\text { between } \\
\text { employees }\end{array}$} & Strongly disagree & 4.5 & 5.3 & 2 \\
\cline { 2 - 5 } & Disagree & 59.1 & 36.8 & 22 \\
\cline { 2 - 5 } & Neutral & 27.3 & 5.3 & 16 \\
\cline { 2 - 5 } & Agree & 4.5 & 36.8 & 52 \\
\cline { 2 - 5 } & Strongly agree & 4.5 & 15.8 & 8 \\
\cline { 2 - 5 } & $\mathrm{p}<0.05$ & \multicolumn{3}{|l}{} \\
\hline
\end{tabular}

Fig 10: Communication channels between employees as barriers to knowledge sharing 


\begin{tabular}{|l|l|l|l|l|}
\hline \multirow{4}{*}{ Item } & \multicolumn{4}{|l|}{ Country } \\
\cline { 3 - 5 } & Response & $\begin{array}{l}\text { India } \\
\mathrm{n}=22\end{array}$ & $\begin{array}{l}\text { Mauritius } \\
\mathrm{n}=19\end{array}$ & $\begin{array}{l}\text { RSA } \\
\mathrm{n}=50\end{array}$ \\
\hline \multirow{4}{*}{$\begin{array}{l}\text { Command and } \\
\text { control } \\
\text { procedures }\end{array}$} & Strongly disagree & 4.5 & 15.8 & 2 \\
\cline { 2 - 5 } & Disagree & 54.5 & 31.6 & 18 \\
\cline { 2 - 5 } & Neutral & 31.8 & 0 & 28 \\
\cline { 2 - 5 } & Agree & 4.5 & 36.8 & 46 \\
\cline { 2 - 5 } & Strongly agree & 4.5 & 15.8 & 6 \\
\cline { 2 - 5 } & $\mathrm{p}<0.0001$ & & & \\
\hline
\end{tabular}

Fig 11: Command and control procedures as barriers to know-ledge sharing

Figures 12 to 16 present the results regarding aspects of knowledge transfer.

\begin{tabular}{|l|l|l|l|l|}
\hline \multirow{4}{*}{ Item } & & \multicolumn{4}{|l|}{ Country } \\
\cline { 3 - 5 } & Response & $\begin{array}{l}\text { India } \\
\mathrm{n}=22\end{array}$ & $\begin{array}{l}\text { Mauritius } \\
\mathrm{n}=19\end{array}$ & $\begin{array}{l}\text { RSA } \\
\mathrm{n}=50\end{array}$ \\
\hline \multirow{4}{*}{$\begin{array}{l}\text { Knowledge } \\
\text { is easily }\end{array}$} & Strongly disagree & 0 & 0 & 6 \\
\cline { 3 - 5 } $\begin{array}{l}\text { accessed } \\
\text { within } \\
\text { departments }\end{array}$ & Disagree & 9.1 & 15.8 & 18 \\
\cline { 2 - 5 } & Neutral & 4.5 & 26.3 & 22 \\
\cline { 2 - 5 } & Agree & 59.1 & 52.6 & 54 \\
\cline { 2 - 5 } & Strongly agree & 27.3 & 5.3 & 0 \\
\cline { 2 - 5 } & $\mathrm{p}=0.10$ & \multicolumn{3}{|l}{} \\
\hline
\end{tabular}

Fig 12: The ease with which knowledge is transferred within departments 


\begin{tabular}{|l|l|l|l|l|}
\hline \multirow{4}{*}{ Item } & \multicolumn{4}{|l|}{ Country } \\
\cline { 3 - 5 } & Response & $\begin{array}{l}\text { India } \\
\mathrm{n}=22\end{array}$ & $\begin{array}{l}\text { Mauritius } \\
\mathrm{n}=19\end{array}$ & $\begin{array}{l}\text { RSA } \\
\mathrm{n}=50\end{array}$ \\
\hline \multirow{4}{*}{$\begin{array}{l}\text { Knowledge } \\
\text { is easily } \\
\text { accessed } \\
\text { from other } \\
\text { departments }\end{array}$} & Strongly disagree & 4.5 & 5.3 & 6 \\
\cline { 2 - 5 } & Disagree & 9.1 & 26.3 & 48 \\
\cline { 2 - 5 } & Neutral & 50 & 31.6 & 42 \\
\cline { 2 - 5 } & Agree & 31.8 & 31.6 & 4 \\
\cline { 2 - 5 } & Strongly agree & 4.5 & 5.3 & 0 \\
\hline
\end{tabular}

Fig 13: The ease with which knowledge is accessed from other departments

\begin{tabular}{|l|l|l|l|l|}
\hline \multirow{4}{*}{ Item } & \multicolumn{4}{|l|}{ Country } \\
\cline { 3 - 5 } & Response & $\begin{array}{l}\text { India } \\
\mathrm{n}=22\end{array}$ & $\begin{array}{l}\text { Mauritius } \\
\mathrm{n}=19\end{array}$ & $\begin{array}{l}\text { RSA } \\
\mathrm{n}=50\end{array}$ \\
\hline \multirow{4}{*}{$\begin{array}{l}\text { Transferred } \\
\text { knowledge } \\
\text { reliable }\end{array}$} & Strongly disagree & 0 & 0 & 0 \\
\cline { 2 - 5 } & Disagree & 0 & 10.5 & 18 \\
\cline { 2 - 5 } & Neutral & 4.5 & 10.5 & 30 \\
\cline { 2 - 5 } & Agree & 81.8 & 73.7 & 48 \\
\cline { 2 - 5 } & Strongly agree & 13.6 & 5.3 & 4 \\
\cline { 2 - 5 } & $\mathrm{p}<0.05$ & \multicolumn{3}{|l}{} \\
\hline
\end{tabular}

Fig 14: The reliability of transferred knowledge 
Knowledge Sharing in HE Human Resources Management

\begin{tabular}{|l|l|l|l|l|}
\hline \multirow{4}{*}{ Item } & \multicolumn{4}{|l|}{ Country } \\
\cline { 3 - 5 } & Response & $\begin{array}{l}\text { India } \\
\mathrm{n}=22\end{array}$ & $\begin{array}{l}\text { Mauritius } \\
\mathrm{n}=19\end{array}$ & $\begin{array}{l}\text { RSA } \\
\mathrm{n}=50\end{array}$ \\
\hline \multirow{4}{*}{$\begin{array}{l}\text { Transferred } \\
\text { knowledge } \\
\text { up-to-date }\end{array}$} & Strongly disagree & 0 & 0 & 0 \\
\cline { 2 - 5 } & Disagree & 0 & 15.8 & 26 \\
\cline { 2 - 5 } & Neutral & 4.5 & 15.8 & 44 \\
\cline { 2 - 5 } & Agree & 81.8 & 57.9 & 26 \\
\cline { 2 - 5 } & Strongly agree & 13.6 & 10.5 & 4 \\
\cline { 2 - 5 } & $\mathrm{p}<0.0001$ & \multicolumn{3}{|l}{} \\
\hline
\end{tabular}

Fig 15: The currency of transferred knowledge

\begin{tabular}{|l|l|l|l|l|}
\hline \multirow{4}{*}{ Item } & \multicolumn{4}{|l|}{ Country } \\
\cline { 3 - 5 } & Response & $\begin{array}{l}\text { India } \\
\mathrm{n}=22\end{array}$ & $\begin{array}{l}\text { Mauritius } \\
\mathrm{n}=19\end{array}$ & $\begin{array}{l}\text { RSA } \\
\mathrm{n}=50\end{array}$ \\
\hline \multirow{2}{*}{$\begin{array}{l}\text { Decisions can } \\
\text { be made } \\
\text { confidently } \\
\text { using }\end{array}$} & Strongly disagree & 0 & 0 & 0 \\
\cline { 2 - 5 } $\begin{array}{l}\text { available } \\
\text { knowledge }\end{array}$ & Disagree & 0 & 5.3 & 26 \\
\cline { 2 - 5 } & Neutral & 4.5 & 21.1 & 42 \\
\cline { 2 - 5 } & Agree & 77.3 & 63.2 & 30 \\
\cline { 2 - 5 } & Strongly agree & 18.2 & 10.5 & 2 \\
\hline
\end{tabular}

Fig 16: The usefulness of available knowledge in giving confidence to decisions

Respondents across all sites agreed that $\mathrm{HR}$ policies and procedures encouraged knowledge sharing at their University. However, there was significant disagreement on the role of unwritten HR policies and procedures at each site. While only $18.2 \%$ and $42.2 \%$ of respondents agreed that unwritten HR policies and procedures encouraged knowledge sharing in India and Mauritius respectively, the majority (68\%) of respondents in South Africa believed that unwritten policies and procedures encouraged knowledge sharing 
at their University. There was agreement across all three sites that job manuals and HR filing systems were operational mechanisms that encouraged knowledge sharing. The majority of respondents in Mauritius (73.7\%) and South Africa $(70 \%)$ believed that workflow processes at their University encouraged knowledge sharing, while only $40.9 \%$ of respondents in India shared this belief.

While the majority respondents in India (63.6\%) did not find their organisational structures to represent a barrier to knowledge sharing, the majority of respondents in Mauritius (52.7\%) and South Africa (62\%) did believe that their organisational structures were barriers to knowledge sharing at their respective Universities. Political interference was not seen to be a barrier to knowledge sharing by $45.5 \%$ of respondents in India. However, a similar proportion of respondents in India (40.9\%) chose to a neutral response to this statement. The majority of South African respondents (62\%) also chose a neutral response to political interference being a barrier to knowledge sharing. In Mauritius however, almost one half of respondents (47.4\%) did believe that political interference represented a barrier to knowledge sharing. Over half the respondents in each of Mauritius (52.6\%) and South Africa (60\%) believed that the lack of adequate communication channels between employees was a barrier to knowledge sharing at their Universities. Similarly, over half the respondents in Mauritius (51.6\%) and South Africa (52\%) believed that Command and Control Regulations represented barriers to knowledge sharing at their Universities.

The majority of respondents across all sites believed that knowledge was easily accessed within departments. However, only $36.3 \%$ in India and $36.9 \%$ in Mauritius believed that this was true for access to knowledge from other departments. Only 4\% of South African respondents believed this to be so at their University. Significantly, the majority (54\%) of South African respondents did not believe that knowledge was easily accessed across departments. Transferred knowledge was believed to be reliable and up-to-date by the majority of respondents in both India and Mauritius. However, only 52\% of South African respondents believed that transferred knowledge was reliable, and only $30 \%$ believed that transferred knowledge was reliable. Again, while the majority of respondents in India and Mauritius were confident about the usefulness of available knowledge for decision-making purposes, only $32 \%$ of their South African counterparts believed that available knowledge could be used confidently in decision-making. 


\section{Discussion}

According to Holsapple and Joshi (1998:14), 'knowledge generation is a knowledge manipulation activity that produces knowledge by processing existing knowledge where the latter has been acquired by selection, acquisition and/or prior generation'. The sub-activities related to knowledge generation include monitoring the organization's knowledge resources, evaluating organizational knowledge, production of knowledge from existing knowledge resources and transfer of the generated knowledge. Human resource departments (HR) play a significant role in facilitating the knowledge generation and knowledge sharing processes of its employees. The important factors that have been selected as contributors to these processes are the impact of HR policies, procedures and unwritten practices, job manuals, filing/record systems and work flow.

Viljoen (2008) states that considerable time and effort could be saved if policies and procedures are documented and implemented accordingly. The common majority belief across survey sites that existing policies and procedures encouraged knowledge sharing demonstrates there is a growing recognition in the HR departments in HEI's about the importance of knowledge and knowledge management policies and procedures to encourage knowledge generation and knowledge sharing. These conventional HR methods may serve as important vehicles for the knowledge management agenda in current times.

Pugh and Hickson (1976) believe that documenting or not documenting HR practices depends on the organizational size, as well as the nature of the organization. The results to this question yielded significantly different responses across survey sites. Respondents from India particularly, but also Mauritius, although to a lesser extent, felt neutral about the role of unwritten HR practices and procedures in augmenting knowledge sharing. The majority of respondents from South Africa, however, demonstrate support for unwritten HR practices and procedures as a means to encourage knowledge generation and knowledge sharing. It does appear that HEI's in South Africa are moving towards flexible decision-making and hence policies may not be written down to achieve the organization's HR objectives.

According to Vegter (1980:69) a job manual prescribes a fixed 'modus operandi' or a plan of action that outlines the method that must be followed to complete certain work-related activities. Similar to support for written HR 
policies and practices, the role of job manuals in promoting knowledge sharing has been universally supported across survey sites. These findings suggest an opportunity for institutions to give additional attention to compiling and raising awareness of job manuals as a knowledge management tool. The results demonstrate support for the maintenance of HR filing systems, more so in South Africa and Mauritius. This could be an affirmation of the heavy reliance on manual human resource information systems. The neutrality of almost a third of respondents from India regarding conventional HR filing systems might represent the technological shift currently being experienced in the country, with electronic filing systems rapidly gaining preference. According to Johnson (1998:123-124), proper workflows among employees in organizations contribute significantly to the achievement of organizational aims and objectives. Support for the role of workflow processes in the promotion of knowledge sharing was demonstrated by the majority respondents in South Africa and Mauritius, where team structures remain rigid and organisations are less fluid in way in which their employees' roles link. In India, however, over one half of respondents chose to remain neutral on the role of workflow processes in promoting knowledge sharing. Newell et al. (2002:14) posit that organizations are changing from the traditional command and control structures to flatter, decentralized structures that are flexible, fluid, networked, and integrated. This leads to the creation of 'business units that are interdependent, relying on one another for critical skills and knowledge'. The majority of respondents from India expressed disagreement with the assertion that organizational structure served as a barrier to knowledge sharing. This is likely to be a reflection of the fact that higher education institutions in India tend to have flatter structures with decentralized teams and a high work ethic. All of these factors have been associated with improved knowledge generation and sharing.

The majority of respondents from India disagreed with the assertion that political interference was a barrier to knowledge generation and sharing. This is expected in a nation that has increasingly valued commercial transparency and has invested greatly in the sharing of institutional knowledge within and between institutions. Perhaps India's best known reflection of their promotion of knowledge sharing is its liberal patent laws. Almost a half of respondents in Mauritius did believe that political interference was a barrier to knowledge sharing. This is concerning, but fits in with its ranking as the third lowest scoring African nation on the Corruption Perception Index by 
Transparency International. As a relatively small nation, there is significant government involvement in all spheres including the economy, and this is possibly being reflected the results of this study. The selection of the neutral position by $62 \%$ of South African respondents is concerning, especially given the present turbulent socio-political landscape of the country, and the increasing concerns over the influence of government over business and vice versa. The majority selection of the neutral response can unfortunately not be elucidated further, but important considerations must include potential fear that respondents might have felt to outrightly declare their concerns of political interference given the current political environment.

The results reflect that communication channels between employees require much attention in South Africa and Mauritius, and India to a lesser degree. In overcoming communication barriers, an environment conducive to knowledge generation and knowledge sharing must be fostered, without which any institutional level knowledge-sharing endeavour is bound to fail. Reasons for seemingly poor communication channels between employees in South Africa were not assessed in this, but previous issues related to workplace diversity, particularly related to dimensions of race, ethnicity, home-language, and gender, are likely to feature highly in a country with such a diverse workforce.

Turban, Mclean \& Wetherbe (1996) posit the need for autocratic decision-making to be replaced by group decision-making through selfdirected teams. Whilst the majority of participants from India state that command and control procedures do not pose as barriers to knowledge generation and sharing, the results reveal that Mauritius and South Africa maintain strong command and control processes that inhibit knowledge generation and sharing. The command and control approach is often inhibitory on an activity, knowledge sharing in this case, through employees' fear of negative sanctions for deviation from perceived commands. This is a reflection of rigid hierarchical organisational structure, whether formal or informal, and detracts from the growing call for a flatter structure to reduce the need for command and control practices.

The results of this study reveal that all nations find knowledge to be more easily accessible within departments, this accessibility is limited when knowledge sharing is between departments. South Africa, in particular, has an alarming problem with the accessibility of knowledge between departments, with only $4 \%$ of respondents agreeing that knowledge could be easily accessed 
from other departments. Possible reasons for this would include silo departmentalisation with limited cross-functionality, and the lack of a common mechanism to store and access knowledge from. Based on the findings, it would appear that South Africa, Mauritius and India have yet to embrace the importance of broader access to knowledge to other sectors within the institution.

According to Alavi and Leidner (2001), empirical studies have shown that while organizations create knowledge on the one hand, paradoxically, they also lose track of acquired knowledge. They therefore posit that storage, organization, and retrieval of organizational knowledge, also termed organizational memory, is an important aspect of effective knowledge management. They claim that the knowledge transfer would include knowledge residing in various mediums, including written documentation; structured information stored in electronic databases; codified human knowledge stored in expert systems; documented procedures and processes; and tacit knowledge acquired by individuals and networks of individuals.

The results demonstrate that knowledge that is transferred is to a large extent, reliable. This augers well for organizations in that sound decisions could be made based on the reliability of the knowledge that is accessed. The fact that the knowledge transferred is reliable is an indication that proper infrastructures are in place to ensure accurate capture, storage, retrieval, and transfer of such knowledge. In addition, it signals confidence in the knowledge.

Alavi and Leidner (2001) emphasize the need for continuous renewal of data, information and knowledge in the knowledge repositories to ensure that decisions are based on current and not out-dated knowledge. The results amongst the countries surveyed show a wide variance in the responses which indicate that institutional practices in updating information and knowledge differs from country to country. Less than a third of South African respondents believed that available knowledge was up to date. This could be attributed to several factors, including but not limited to the lack of updating IT records effectively with the latest information and knowledge. Whatever the reasons, a concern that available information is dated might limit employees' willingness to share or use such information. Indeed, again less than a third of South African respondents believed that decisions could be made confidently using available information. This result could be an indication that South African institutions are not sufficiently codifying and storing knowledge. Newell et al. (2002) ascribe ineffective decision-making due to lack of 
information/knowledge resources to two key reasons. Firstly, organizations grapple with the codification and capture of critical knowledge, and secondly, employees are reluctant to have their personal knowledge committed to organizational memory as they view such an act as a reduction of the knowledge power base.

\section{Conclusion}

Knowledge sharing is a strategic tool for human resource management in higher education institutions in the 21 st century organizational era. This turbulent environment poses new challenges to organizations, and there is an urgent need for a drastic shift in human resource roles, functions and responsibilities. In the perceived absence of enabling factors to encourage employees to share knowledge, it is an extremely difficult task to ensure that the right knowledge is in the right place at the right time to assist in efficient decision-making. Institutions should invest in knowledge sharing enablers such as IT infrastructure, creating organizational structures that foster teamwork, implement mentorship programmes, encourage job rotation to facilitate multiskilling, and implement the characteristics of learning organizations. Rigid hierarchical structures, anti-social cultural traditions, unfriendly KM/HRM policies, and communication barriers represent threats to the adoption of knowledge management at higher education institutions. Therefore, the need to overcome these obstacles by devising innovative interventions such that the HRM managerial concern could be transformed into effective managerial ability must be regarded as a priority for human resource management and executive management.

\section{References}

Ahmed, P.K., K.K. Lim \& A.Y.E. Loh 2002. Learning through Knowledge Management. Oxford: Butterworth-Heinemann Ltd.

Alavi, M. \& D. Leidner 2001. Review: Knowledge Management and Knowledge Management Systems: Conceptual Foundations and Research Issues. MIS Quarterly 25,1: 107 - 136. https://doi.org/10.2307/3250961

Bassi, L.J. 1997. Harnessing the Power of Intellectual Power. Training and Development 12,1: 25 - 30 . 
Rubeshan Perumal, Sadhasivan Perumal \& Loganathan N. Govender

Castells, M. 1989. The Informational City: Information Technology, Economic Restructuring and the Urban-regional Process. Blackwell. Oxford.

Chivu, I. \& D. Popescu 2008. Human Resource Management in Knowledge Management. Revista Informatica Economica $4,48: 54$ - 60.

Cloete, N., I. Bunting \& T. Kulati 2000. Higher Education Leadership Challenges in 1999. CHET \& UNCF

Cloete, N. \& I. Bunting 2008. Higher Education Transformation. Pretoria: CHET.

Craib, I. 1997. Classical Social Theory. Oxford: Oxford University Press.

Davenport, T.H. \& L. Prusak 1998. Working Knowledge. Boston: Harvard Business School Press.

Dess, G. \& J. Picken 1999. Beyond Productivity: How Leading Companies Achieve Superior Performance by Leveraging their Human Capital. New York: American Management Association.

Drucker, P.F. 1993. Post Capitalist Society. Oxford: Butterworth-Heinemann. Gottschalk, P. 2005. Strategic Knowledge Management Technology. USA: Idea Group Publishing.

https://doi.org/10.4018/978-1-59140-336-4

Govender, L.N., R. Perumal \& S. Perumal 2018. Knowledge Management as a Strategic Tool for Human Resource Management at Higher Education Institutions. South African Journal of Information Management 20,1: a966. https://doi.org/10.4102/sajim.v20i1.966

Grover, V. \& T.H. Davenport 2001. General Perspectives on Knowledge

Management. Journal of Management Information Systems 18,1: 5 - 21. https://doi.org/10.1080/07421222.2001.11045672

Herling, R.W. \& J. Provo 2000. Knowledge, Competence and Expertise in Organizations. San Francisco: AHRD/Berrett-Koehler Communications Inc. https://doi.org/10.1177/152342230000200102

Holsapple, C.W. \& K.D. Joshi 1998. In Search of a Descriptive Framework for Knowledge Management: Preliminary Delphi Techniques. Kentucky Initiative for Knowledge Management 118: 1-27.

IMD 1998. World Development Report (1998): Knowledge for Development.

World Bank.

IMD 2007. World Competitiveness Yearbook: The Big Shake Up! The Race is on to Catch up with the US. Press Release, 10 May 2007.

Ivancevich, J.M. 2001. Human Resource Management. $8^{\text {th }}$ Edition. McGrawHill, New York. 
Johnson, D. 1998. Human Resource Management in the Tourism Industry. Australia: McGraw-Hill.

Kaniki, A.M. 2005. Workshop on Knowledge Management with a Focus on the Higher Education Sector. Pietermaritzburg: University of KwazuluNatal.

Lengnick-Hall, M. \& C.A. Lengnick-Hall 2003. Human Resource Management in the Knowledge Economy: New Challenges, New Roles, New Capabilities. Berrett-Koehler Publishers.

Leopold, J., L. Harris \& T. Watson 2005. The Strategic Managing of Human Resources. England: Ashford Colour Press Ltd., Gosport.

Little, S., P. Quintas \& T. Ray 2002. Managing Knowledge: An Essential Reader. Milton Keynes: The Open University, Sage Publications.

Markus, M.L. 2001. Towards a Theory of Knowledge Re-use. Journal of Management Information Systems 18,1: 57 - 93.

https://doi.org/10.1080/07421222.2001.11045671

Marshall, N. \& T. Brady 2001. Knowledge Management and the Politics of

Knowledge: Illustrations from Complex Product Systems. European Journal of Information Systems 10: 99 - 112.

https://doi.org/10.1057/palgrave.ejis.3000398

Mayo, A. 1998. Memory Bankers. People Management January 22: 34 - 38. Momberg, E. 2008. Brain Drain: You ain't seen nothing yet. Sunday Tribune August 31: 12.

Newell, S., M. Robertson, H. Scarbrough \& J. Swan 2002. Managing Knowledge Work. New York: Palgrave Macmillan.

O’Dell, C. \& C. Grayson C 1998. If only we knew what we know: Identification and Transfer of Internal Best Practices. California Management Review 40,3: 154 - 174.

https://doi.org/10.2307/41165948

Pugh, D.S. \& C.D. Hickson 1976. Organization Structure: Extensions and Replications. Farnborough: Saxon House.

Scarbrough, H. 1999. Knowledge as Work: A Conflict-based Analysis of the Management of Knowledge Workers. Technology Analysis and Strategic Management 11,1: 5 - 16.

https://doi.org/10.1080/095373299107546

Smith, H. \& W. Schurink 2005. The Interface between Knowledge Management and Human Resources: A Qualitative Study. SA Journal of Human Resource Management 3,1: 6 - 13. 
Rubeshan Perumal, Sadhasivan Perumal \& Loganathan N. Govender

https://doi.org/10.4102/sajhrm.v3i1.58

Storey, J. \& E. Barnett 2000. Knowledge Management Initiatives: Learning from Failure. Journal of Knowledge Management 4,2: 145 - 156.

https://doi.org/10.1108/13673270010372279

Storey, J. \& P. Quintas P 2001. Knowledge Management and HRM. London: Thomas Learning.

Straker, D. 1998. Quo vadis nunc: Where Does an Innovative Company Go Next? Paper presented at MKIRU workshop, 'Building and maintaining the capability to innovate workshop'. The Open University, Milton Keynes, 30 September 1998.

Sveiby, K. 2001. Knowledge Management - Lessons from the Pioneers. Available at: http://www.sveiby.com/KM-lessons.doc (Accessed on 8 May 2002.)

Svetlik, I. \& E. Stavrou-Costea 2007. Connecting Human Resources Management and Knowledge Management. International Journal of Manpower 28, 3: 197 - 208.

https://doi.org/10.1108/01437720710755209

Viljoen, N. 2008. Believe it or not, paperwork should raise productivity. Daily News, Business Report, October 2, 2008.

Watson, T.J. 1999. Strategic Human Resourcing: Principles, Perspectives, and Practices. London: FT/Pitman Publishing.

Wessels, J.H. 2000. Draft Note on Promotion of Access to Information Act 2 of 2000. Justice College, South Africa.

Rubeshan Perumal Centre for the AIDS Programme of Research in South Africa Nelson R Mandela School of Medicine University of KwaZulu-Natal Durban rubeshanperumal@gmail.com

Sadhasivan Perumal School of Management, IT and Governance University of KwaZulu-Natal Durban perumals@ukzn.ac.za 
Knowledge Sharing in HE Human Resources Management

Loganathan Narayansamy Govender School of Management, IT and Governance University of KwaZulu-Natal Durban govenderln@ukzn.ac.za 